Мирјана Даничић

Сандра Јосиповић

Универзитет у Београду

Филолошки факултет

mirjana.danicic@fil.bg.ac.rs

sandrajosipovic@gmail.com

https://doi.org/10.18485/ai_knjiz_u_prevodu.2019.ch2

$81 ' 255.4$

821.163.41.09 Андрић И.

\title{
ЈЕДАН ПРИМЕР ВРЕДНОВАҢА КЊИЖЕВНОСТИ У ПРЕВОДУ: \\ OMER PASHA LATAS: MARSHAL TO THE SULTAN
}

Роман Иве Андрића Омер-паша Латас (1977) ${ }^{1}$ објављен је на енглеском језику тек 30. октобра 2018. године под називом Omer Pasha Latas: Marshal to the Sultan. Како Андрићев роман одликују сложена структура, отменост језичког израза и стилска изврсност, ауторке рада имају за циљ да анализирају превод романа, а приликом евалуације постигнутих преводилачких решења узимају у обзир теорију дирекционалне еквиваленције. Такође, у раду се разматра интертекстуалност романа и превода како би се испитао ниво еквиваленције у преношењу одређене слике света са једног језика на други.

Кључне речи: Иво Андрић, транслатологија, књижевни превод, еквиваленција, културолошка доместикација, језичка доместикација, интертекстуалност.

1 Као годину издања романа у изворима налазимо 1977, али и 1976. годину. Разлог за ову недоследност налазимо у чињеници да је роман објављен постхумно од рукописа који је остао у Андрићевој заоставштини. 


\section{1. Уводни део}

Међу књижевним критичарима и теоретичарима често се не доводи у питање супериоран положај књижевног превођења у транслатологији (Игњачевић 1988: 122, Сибиновић 1989: 25). Разлози за овакав став могу бити бројни. Пре свега, преводна књижевност представља облик упознавања са „новом духовном и животном средином, често других и другачијих светоназора, навика и обичаја" (Стојнић 1989: 31). Самим тим преводна књижевност доприноси књижевној баштини целокупног човечанства. Затим, на личном нивоу, читајући преводну књижевност, обогаћујемо сопствена сазнања, градимо и усавршавамо сопствени културолошки модел. Такође, интегришемо се, у одређеној мери, у културу народа чијим језиком је изворно дело написано тако што усвајамо неке нове елементе језика, духа, начина живота, кретања, другачије поимање света. Дакле, наше искуство постаје умногоме ${ }^{2}$ обогаћено читањем дела преводне књижевности која су настала у утврђеном цивилизацијском моделу неке друге језичке заједнице. Свест о оволикој важности и улози књижевног превођења ставља пред књижевног преводиоца велику одговорност. С друге стране, његова улога му омогућава да активно учествује у процесу развоја преводне књижевности, али и проучавања превођења (транслатологије), јер ће његова преводилачка решења, посебно ако су иновативна, бити уврштена у преводилачке стратегије и поступке циљног језика. Суочен са одређеним текстом, преводилац мора да изабере одређено тумачење и одговори на сва транслатолошка

2 Овде, као и у наставку текста, ауторке користе курзив за наглашавање. 
питања, а да при томе остане, у што већој мери, веран изворном тексту.

Верност изворном тексту је суштина превођења, али и сваког теоријски или прагматично усмереног проучавања превођења. Један од кључних термина транслатологије је еквиваленција, односно способност преведеног текста да досегне изворник, то јест да превод има исту вредност као изворник (Руm 2010: 7). Вредност речи и идеја се у теоријама превођења друге половине XX века показала као кључна: ако претпоставимо да одређена идеја из једног језика има исту вредност на другом језику и пре него се упустимо у превођење, онда говоримо о природној еквиваленцији (Руm 2010: 6). Различите школе и различити правци су давали различита имена природној еквиваленцији и њеним поткатегоријама. На пример, амерички теоретичар Најда (Eugene Nida), који се у теоријском проучавању превођења не може избећи, говори о формалној и динамичној еквиваленцији. Формална је миметичка, јер се значење преноси реч за реч. Динамична еквиваленција без лексичке мимезе активира идентичну културолошку функцију у језику циља. На сличан начин, руски теоретичар и лингвиста Евгениј Верешчагин разликује инваријантне, рецептивне и индивидуалне чиниоце превођења (Стојнић 1989: 32). Инваријантни чиниоци су они који преносе непромењено значење текста, док рецептивни нису условљени изворником, те долази до неподударања изворника и превода на одређеним језичким нивоима, што диктирају језичка правила циљног језика. Индивидуални чиниоци зависе од самог преводиоца и његовог тумачења текста. Наизглед, појам еквиваленције се чини прилично једноставан, али у преводилачкој пракси се показао као сложен, а у теорији превођења као контроверзан и још сложенији. 
Узимајући у обзир вештине и знања које преводилац мора да поседује пре него што приступи превођењу романа као што је Омер-паша Латас, поменућемо један од аргумената који доприноси поменутој контроверзи, а који наводи амерички теоретичар и критичар Лоренс Венути (Lawrence Venuti) када анализира природну еквиваленцију, односно што већу верност изворнику. Њега посебно занима како у преводној књижевности велики језици перципирају културе остатка света. „Ако је резултат да све културе звуче као течан савремени енглески језик, онда ће англоамеричка култура живети у убеђењу да је цео свет попут ње." (Рут 2010: 21) Зато Венути сматра да је потребно да књижевност у преводу буде отпорна (а еквиваленција не-природна) тако што ће преводилац користити решења која нису уобичајена у језику циља, чак и по цену да форма одудара од изворника (Ibid.). Он, дакле, инсистира на томе да се превод не сме англиканизовати, односно да не сме доћи ни до лексичке, ни до културолошке доместикације. Према Венутију, доместикација превода помаже да се циљној публици транспарентно и јасно пренесе изворно значење (1995: 21), јер се у преводу смањују стране карактеристике језика и културе изворног текста. У одређеној мери, Венутијева идеја је опречна идеји о природној еквиваленцији, јер поред форме и језика наглашава важност преношења ванјезичких елемената у поступку превођења књижевног дела.

Схвативши недоречености и мањак свеобухватности теорија које говоре о природној еквиваленцији, у теорији превођења издвојио се појам дирекционалне еквиваленције, којим се означава асиметричан однос изворника и превода. Ова теорија не узима здраво за готово да би се добио изворни текст ако би се превод превео на језик извора (Рут 2010: 25), дакле природна 
еквиваленција престаје да буде подразумевана категорија. Разлог овоме може бити чињеница да теоретичари дирекционалне еквиваленције прихватају да преводилац има избор између неколико преводилачких стратегија, а те стратегије не диктира језик изворника (Руm 2010: 26). Разумна претпоставка је да их диктирају преводиочева вештина и одређени екстралингвистички фактори. У том случају, вредност текста се мења услед културолошких разлика, намерне манипулације текстом, или одређене преференце преводиоца (Munday 2012: 44). Другим речима, преводилац има могућност избора коју писац оригинала није имао (Стојнић 1989: 34). Преводилац тумачи ауторску позицију на нивоу лексике, структуре, смисла, стила, културолошког и историјског исказа. Самим тим, тумачење књижевног дела је имплицитно самом превођењу. Осим тога, постоје одређене вредности, најпре на микроплану, које преводилац прикривено уноси у превод, најчешће несвесно (Munday 2012: 40). Вредновање једног превода, између осталог, обухвата и препознавање и анализу ових убачених вредности, пре свега на основу лексичких сигнала (Munday 2012: 40-41). Најлакше „жртве” дирекционалне еквиваленције су речи које су богате културолошким, политичким или другим вредностима. На пример, одлука преводиоца да два различита назива истог града које Андрић користи у роману, Стамбол и Цариград, преведе топонимом Истанбул (Istanbul) упркос томе што у енглеском постоје топоними Constantinople (Константинопољ) и Stamboul (Стамбол) указује да ове лексичке јединице можемо посматрати као „осетљиве” вредности (Munday 2012: 41). Приликом превођења осетљивих вредности, преводилац доноси „критичне” (ibid) одлуке.

Иако теорија дирекционалне еквиваленције није отпорна на критике и не решава све дилеме, сматра- 
мо да је потребно да је узмемо у обзир када говоримо о превођењу Андрићевог Омер-паше Латаса, као и сваког другог књижевног дела које представља историјски и културолошки фундамент једног језика. При превођењу таквих књижевних дела, умеће преводиоца да пренесе смисао изворног текста обухвата много више од преводиочевих лингвистичких компетенција, јер су преводилачка решења културолошки условљена. Не смемо заборавити ни естетску особеност текста, која нипошто није најмање важна. Не доводи се у питање да се при превођењу књижевног дела језичка чињеница претвара и у естетску.

Најзад, оправдано је и питање у чему је циљ једне овакве анализе књижевног превода. Пре свега, желимо да испитамо како је преводилац поступио у конфронтацији две језичке норме и две културе, чиме се пружа допринос теоријско-методолошком апарату савремене критике превода, као и теорије превођења у целости. Осим тога, занима нас и историјски аспект, односно утицај који стварно време настанка романа (1977) има на превод (2018) и обрнуто - шта се дешава када се књижевно дело из старије епохе преводи за савременог читаоца. У том смислу, потребно је размотрити интертекстуалност, или прецизније речено дијалог, књижевног дела и превода како би се испитао степен еквиваленције у преношењу одређене слике света са једног језика на други.

2. Анализа превода

2.1. Наслов романа и уводна реченица

Примерено би било да овакву анализу започнемо од наслова романа Омер-паша Латас. На енглеском језику наслов гласи Omer Pasha Latas - Marshal to the 
Sultan ${ }^{3}$. Већ на први поглед примећујемо да је постигнута дирекционална еквиваленција, тј. одређена лексичка асиметричност превода и изворника, јер насупрот Андрићеве две лексичке јединице у енглеском стоји седам лексема. Примењени преводилачки поступак назива се додавање и дефинише као увођење допунских речи (Јовановић 2001: 49-50). Претпостављамо да преводилац полази од тога да превод мора учинити разумљивијим читаоцима и објаснити појам који би могао бити сасвим непознат у читаочевој средини. У овом примеру, узрочник овог поступка је екстралингвистички, јер преводилац претпоставља да читалац не мора бити упознат са историјским ликом Омер-паше и настоји да упозна публику са ширим контекстом, као и да оснажи, интензивира значење на нивоу микроструктуре наслова. Поред тога, можда је постојала и жеља издавача да својеврсном егзотиком наслова привуче већи број читалаца и конкретизује тему романа. Најзад, да би преведено дело нашло своје читаоце у новој средини мора, макар у најмањој мери, испуњавати оно што читаоци очекују од тога дела, што највероватније објашњава зашто је у преводу наслова присутна доместикација.

Други пример који ћемо анализирати је уводна реченица из романа, јер већ на самом почетку видимо неке од омиљених стратегија преводиоца: „После свих наговештаја и говоркања, дошао је заиста дан да у Сарајево уђе сераскер Омерпаша са својом војском." (1981: 9) Важно је напоменути да је Андрић читаоцима обезбедио глосар на крају романа, у ком појашњава појмове за које сматра да би читаоцима могли бити

3 Сви цитати преузети су из електронског издања романа на енглеском језику: Andrić, I. Omer Pasha Latas: Marshal to the Sultan. Celia Hawkesworth (prev.). London: Penguin Random House, 2018. Електронско издање Амазона (киндл). 
непознати. У том глосару проналазимо објашњење појма сераскер: главни врховни командант, у случају рата постављан из редова везира (1981: 317). Ако у једнојезичном енглеском речнику потражимо речи из Андрићевог објашњења, пронаћи ћемо да је могуће употребити три преводна еквивалента: commander-inchief, marshal; serask(i)er (a vizier in the Ottoman Empire who commanded an army). Преводилац се одлучио за истовремену употребу два: „After all sorts of hints and rumors, the day finally came when the Ottoman commander in chief, the seraskier Omer Pasha, entered Sarajevo with his army." У повратном преводу, тај део реченице гласио би: „дошао је заиста дан да отомански врховни командант, сераскер Омерпаша уђе у Сарајево”. Дакле, примећујемо да је поново употребљена техника додавања, као и дирекционална еквиваленција, јер једна лексема у српском стоји насупрот седам у енглеском. Поред тога, примећујемо да у преводу постоји делимична доместикација, тј. недостатак Венутијевог „отпорног превода”.

\section{2. Превод географских имена}

Следећи примери које ћемо погледати су топоними, о чијем превођењу је било речи и у уводном делу. Наиме, у студији „Евалуација у превођењу” (Evaluation in Translation), савремени транслатолог Џереми Мундеј наглашава да је „феномен именовања” критичан у поступку превођења: да ли ћемо државу назвати Америка или Сједињене Државе, да ли ћемо град назвати Монтреал или Montréal говори нам о пишчевом (и преводиочевом) позиционирању према историјском и(ли) политичком идентитету датог топонима (Munday 2012: 41). Андрић у роману користи топониме Стамбол (1981: 9, 13, 35, 48) и Цариград (1981: 34), док се прево- 
дилац одлучио да у преводу користи увек исти топоним (Istanbul) иако у енглеском језику постоје Stamboul и Constantinople. Назив града Истанбул ушао је у службену употребу 1930. године, а до тада се користио назив Цариград односно у енглеском језику Constantinople. C обзиром да је Омер-паша Латас живео од 1806. до 1871. године и да радња романа покрива тај историјски период, назив града на енглеском би требало да носи исту историјску конотацију као изворни текст, јер се писац труди да поштује историјске факте у мери да одређени књижевни критичари роман сврставају у историјски. Ако дубља анализа покаже, као што се нама чини, да писац упадљиво разликује употребу два топонима Стамбол и Цариград, односно да је Стамбол назив који у роману користе становници тог града и целокупна војска Отоманског царства, самим тим и Омер-паша Латас, а да је Цариград назив који користе становници царства у поробљеним земљама, што су у роману становници Босне, онда би било потребно у преводу истаћи ову значењску нијансу: док је за део становништва назив града пуки географски појам, за други (поробљени) део је то град у ком живи и царује цар (царски град, односно Цариград).

Обратићемо пажњу и на превод неких локалних топонима. Уз Бистрик (1981: 59) је у преводу употребљена заједничка именица која има за циљ да појасни да је то брдовит део града (Bistrik Hill), као и Миљацка уз коју је употребљена заједничка именица која објашњава да је у питању река (the Miljacka river). Исти поступак преводилац примењује и за називе улица: кућа на Широкачи (1981: 67) у преводу постаје кућа у улици Широкача (on Širokača Street), као и за називе сеоских насеља - Mетаљка (1981: 68) је у преводу проширено у Метаљка у источном делу земље (Metaljka in the east of the country). 
Сматрамо да је у наведеним примерима оправдан поступак додавања интратекстуалне глосе (Munday 2012: 111), јер има за циљ да страним читаоцима појасни нешто што је добро познато локалном становништву. Јовановић додавање уз географска имена назива опционалним додавањем, јер је условљено потребама крајњег корисника превода (2001: 50).

Ипак, стратегија додавања у циљу појашњења топонима не може се извући као опште начело у преводу Андрићевог романа, јер се понекад преводилац одлучује за нулту еквиваленцију, односно бира да топоним не преведе. На пример, на самом почетку поглавља „Вино звано Жилавка”, помиње се велика, лепа кућа на Бјелавама (Андрић 1976: 75), док је у преводу описана лепа и велика кућа чија локација није преведена.

Из наведених примера може се видети да су топоними, као и лична имена, у преводу остављени у изворном облику. Међутим, преводилац је на почетку књиге у уводној напомени објаснио како се изговарају поједини гласови српског језика: $u, u, \hbar, u, \hbar, j, u$ и ж. Занимљиво је како преводилац објашњава изговор гласа Ђ: „ $d j$, готово једнак изговору $d z ̌$, али је мекши, тј. као $d$ у verdure”. Код преводиоца није постојала жеља да имена англиканизује, већ је сматрао да ће се задржавањем изворних назива задржати локални колорит места и ликова који се помињу у роману. Венутијевим речима, превод није прилагођен него је остао отпоран на страни утицај.

\section{3. Превод позајмљеница}

Предмет наше анализе били су и преводи позајмљеница. Примећено је да је, приликом превода позајмљеница, преводилац примењивао две стратегије: или је 
задржавана изворна реч, праћена објашњењем, односно примењен је поступак додавања, или је у преводу задржана изворна реч без објашњења. Навешћемо неколико примера. Реченица „Игра се краковјак [...] (Андрић 1976: 80)” преведена је реченицом: „They danced a Krakoviak polka [...]" Следећа два примера илуструју формалну еквиваленцију. Реч „мелшпајз” (Андрић 1976: 79) преведена је позајмљеницом mehlspeise без додатног објашњења. Иста стратегија примењена је у превођењу речи „чардаш” (Андрић 1976: 80) тако што је у преводу задржана мађарска реч czardas без објашњења.

Приликом превођења неких турцизама примењена је доместикација, што није у складу са поменутим Венутијевим уверењем да се превод не сме англиканизовати, односно да не треба примењивати лексичку, нити културолошку доместикацију. Она се ипак може уочити у следећим примерима: „Џенетића конаци” (Андрић 1976: 61) преведени су као резиденција Џенетића (the Dženetić residence); именичка фраза „сутрашњи таин” (Андрић 1976: 67) преведена је клаузом (whether he will eat tomorrow), а без именице која би била еквивалентна именици турског порекла - таин, која означава војнички оброк, војнички хлеб (Стевановић 1976: 125). У овом примеру примењена је дирекционална еквиваленција, јер се значење у преводу преноси већим бројем лексема у односу на извор. Међутим, упркос већем броју лексема, у преводу се губи део значења именице „таин”, посебно јер се у датом контексту описује војник (Андрић 1976: 67). Придев низамски представља још један пример исте преводилачке стратегије: „[...] неодређене одвратности према свему што је сераскерово и низамско [...]” (Андрић 1976: 62). Турцизми „сераскерово” и „низамско” преведени су нефинитном клаузом у којој је задржан први турцизам, али не и други (pertaining to 
the seraskier and the army) иако у енглеском језику постоји одговарајућа турска позајмљеница (nizam) која означава некадашњег турског војника. Дакле, преводилац се одлучио да придев „низамско” преведе домаћом речју која означава војску (army), на тај начин применивши доместикацију.

Анализа је показала да постоји доместикација у великом обиму. Навешћемо неколико примера: именица „магазе” (Андрић 1976: 62) преведена је домаћом именицом (storerooms); именица „бадаваџија” (Андрић 1976: 75) такође је преведена домаћом именицом (idlers); именичка фраза „у сарајевској чаршији” (Андрић 1976: 69) преведена је фразом која уместо речи турског порекла садржи домаћу реч (in the Sarajevo business world); именичка фраза „испод сећије” (Андрић 1976: 64) преведена је фразом нешто општијег значења која не садржи турцизам (under a bench); именичка фраза „из мутвака” (Андрић 1976: 78) пренета је фразом која садржи домаћу реч (from the kitchen); именица „миндерлук” (Андрић 1976: 78) преведена је именицом нешто општијег значења (sofa); именичка фраза „на диванани” (Андрић 1976: 80) преведена је фразом која не садржи позајмљеницу, него културолошку референцу циљне културе (салон у значењу просторије у којој се пије чај, воде друштвени разговори, читају новине, пуши), чиме се превод „одомаћује” (in the drawing room). Део реченице „[...] чим се смркне, искупљају шејтани и играју коло” (Андрић 1976: 63) преведен је без турцизма који би одговарао позајмљеници шејтан (sheitan), која у енглеском језику постоји као англиканизована верзија овог турцизма. Примећујемо да ни за елемент музичког фолклора није употребљена именица еквивалентног значења (as soon as darkness fell [...] devils gathered to dance) иако у енглеском језику постоји адекватан израз (wheel dancing) 
да означи народну игру „коло” (Бујас 2005: 545). Најзад, именица „аскер” (Андрић 1976: 66) преведена је домаћом именицом која означава полицајца (policeman) мада би прецизнији превод те именице подразумевао да се читаоцима пренесе да аскер означава турског војника (Стевановић 1967: 103).

С друге стране, проналазимо примере превода турцизама у којима је примењена дирекционална еквиваленција уместо доместикације. Када је у питању превод именице „Топчибаша” (Андрић 1976: 75), задржан је турцизам Topčibaša, али преводилац додаје интратекстуално објашњење да је у питању Cannon Master. Beћ смо показали да је именица „сераскер” (Андрић 1976: 61) пренета у енглески језик именицом турског порекла (seraskier). Именица „харем” (Андрић 1976: 61) такође је преведена именицом турског порекла (harem), као и именица „бегови” (Андрић 1976: 69), која је преведена турцизмом (beys). Културолошки елемент који означава део народне ношње „фес” (Андрић 1976: 67) преведен је турцизмом (fez).

На основу наведених примера, долазимо до закључка да се у овом преводу ниједна стратегија не истиче као доминантна: ни доместикација, ни формална еквиваленција, као ни дирекционална еквиваленција. Преводилац се одлучује за одређено решење према сопственим критеријумима, зависно од тога како оцењује способност будућих читалаца да разумеју текст који обилује страним речима.

\section{4. Језичка реорганизација}

Током анализе, уочен је само један пример језичке реорганизације, што указује на чињеницу да се преводилац начелно држао изворне дужине Андрићевих 
реченица. Следећу сложену реченицу преводилац је поделио на две: „А нови становници Џенетићевих конака и суседних зграда, са своје стране, гледају опет са неповерењем и презиром на те грађане који се клоне њих и њихових кућа и заобилазе царског човека где год могу, а кад баш морају да га сретну, пролазе мимо њега као потуљене кукавице нејасних намера и подмукла изгледа" (Андрић 1976: 62). Уместо зареза који стоји у изворној реченици иза „где год могу” у енглеској реченици стављена је тачка: „And, for their part, the new inhabitants of the Dženetić residence and neighbouring buildings looked with distrust and contempt at the citizens who shunned them and their houses and avoided the sultan's representatives whenever they could. And when they could not help coming face to face with any of them, they passed them like cowards of unclear intentions and sly appearance." Ово је усамљени пример да се преводилац одлучио да стилски прилагођава Андрићев израз, што треба похвалити, јер је на тај начин у преводу задржана поетика изворног текста. С обзиром да српски и енглески језик нису сродни, напор преводиоца да очува стилску вредност изворног израза утолико је већи.

\section{5. Индивидуални чиниоци}

Анализа је показала да се у преводу романа могу пронаћи примери Верешчагинових индивидуалних чинилаца превођења (Стојнић 1989: 32). Они зависе од самог преводиоца и његовог тумачења текста. На пример, преводилац је одлучио да преведе српску именицу „брлог” (Андрић 1976: 63) енглеском именицом pigsty која значи свиғаи (Дрводелић 1973: 733) упркос томе што се именица „брлог” може превести енглеском именицом истог значења - lair (Бујас 2005: 124). 
Такође, понекад је преводилац одлучио да у преводу изостави одређене речи. На пример, у делу реченице „[...] у коме врви и режи неука и убога, осиона и тврдоглава босанска руља” (Андрић 1976: 63), глаголи „врви” и „режи” преведени су једним глаголом (to seethe) који значи „кипити, врити; ускомешати се, узбуркати се” ([...] seething with the uneducated and impoverished, proud and stubborn Bosnian rabble).

Сликовит атрибут „потуљен” који, између осталог, може да значи притајен, подмукао (Стевановић 1971: $810)$, изостављен је у преводу фразе „потуљене кукавице” (Андрић 1976: 62). Ова именичка фраза једноставно је преведена именицом кукавице (cowards). У оба наведена примера, преводилац је применио одузимање и изостављање (Јовановић 2001: 56). Према Јовановићу, одузимање, као и додавање, није нешто што преводилац намерно ради, већ се труди да постигне највернији превод према критеријуму садржаја и значења (ibid).

У делу реченице „[...] неко од другова да поседи са њим и прикрати време и себи и њему" (Андрић 1976: 64) именица „другови” преведена је именицом која означава колеге (colleagues, Дрводелић 1973: 162) мада се лако може закључити из контекста да су у питању војници. Израз „прикрати време” преведен је изразом који значи „помоћи да време прође” (to help the time pass) иако у енглеском постоји одговарајући израз (to kill time = to spend time doing something that is not important while you are waiting for something else to happen, Wehmeier 2003: 708). Одлука преводиоца који чита и тумачи дело је дефинитивна, али сматрамо да би у преводу овог израза глагол to kill који значи убити (Дрводелић 1973: 530) вероватно био адекватнији у датом контексту у којем се помиње војска.

Када је реч о индивидуалним чиниоцима, занимљиво је погледати резултате анализе превода оних имени- 
ца које су у роману употребљене више пута. Мишљења смо да је преводилац оправдано донео одлуку да именицу „чамотиња” различито преводи у складу са датим контекстом. У примеру „[...] о чамотињи босанских села и градова” (Андрић 1976: 64), именица је преведена на следећи начин: „[...] tedium of Bosnian towns and villages". Именица tedium значи досада, једноличност (Дрводелић 1973: 992). У примеру „[...] чамотиње овог јесењег вечера [...]” (Андрић 1976: 68) иста именица преведена je „[...] melancholy of this autumn evening [...]", дакле именицом melancholy која означава меланхолију, тугу, сету (Дрводелић 1973: 608).

Ако тражимо разлоге за наведене интервенције у тумачењу изворног текста, треба имати у виду да превођење књижевности написане на српском језику на енглески језик није интензивно, самим тим готово сваки превод мора бити урађен тако да налази своје оправдање да постане језичка и културна чињеница у циљном језику и култури. У супротном, превод ће остати само библиографска јединица. Дакле, преводилац је дужан да пронађе одговарајућу стратегију којом ће не само приступити преводилачком послу, већ и промовисати преведен текст. Чињеница да је превод романа Омер-паша Латас ушао у најужи избор за награду за најбољи књижевни превод на енглески језик урађен у 2018. години, коју додељује Универзитет у Оксфорду под покровитељством фондације Вајденфелд, ${ }^{4}$ говори о томе да је стратегија за коју се одлучио преводилац овог романа оцењена као изузетно успешна у циљној култури.

4 Све информације о награди Оксфорд-Вајденфелд која се додељује за најбољи књижевни превод урађен у претходној години налазе се на електронској презентацији Универзитета у Оксфорду: http:// www.st-annes.ox.ac.uk/about/the-oxford-weidenfeld-translation-prize. 


\section{6. Историјска интертекстуалност романа и превода}

Као последњи предмет анализе узели смо историјски аспект, односно утицај који стварно време настанка романа (1976-77) има на превод (2018) и обрнуто шта се дешава када се књижевно дело из старије епохе преводи за савременог читаоца. Постоје примери који илуструју да не треба занемарити значај историјског аспекта. Ако погледамо део реченице „[...] као да је на неком комерсу своје студентске корпорације [...]” (Андрић 1976: 79), видећемо да писац користи две позајмљенице - комерс и корпорација. Можемо рећи да се именице комерц и корпорација у савременом српском фреквентно употребљавају, додуше у пословном језику трговине, банкарства, привреде, финансија, јер означавају трговину (комерц) и веће привредно друштво (корпорација). Међутим, у време настанка романа именица „комерс” користи се да означи свечану забаву, гозбу (Стевановић 1967: 801), док се „корпорација” користи да означи друштво, удружење (Стевановић 1967: 858, Вујаклија 1986: 471). Да погледамо како је овај део реченице преведен на енглески језик: „[...] as if at a gathering of his student society [...]". Примећуjeмо да избор именица на енглеском (gathering, society) у потпуности преноси значење изворних именица (gathering = окупљање, society $=$ друштво, Бујас 2005: $354,836)$, али не одражава дијахронијску патину која постоји у изворном тексту, јер је преводилац користио синхрони пресек значења. Оправданост оваквог избора могла би се, с једне стране, наћи у питању сврсисходности трагања за речима које би пренеле значење у дијахронијској равни, а са друге у привидној сличности речи коришћених на разним ступњевима језичког раз- 
воја. Те речи се лако могу разумети и као лажни парови уколико читалац није упознат са дијахронијским значењем. У том смислу, може се рећи да се води непрестани дијалог између изворног текста и преводиоца, да је тумачење текста имплицитно процесу превођења и да подразумева свестрану анализу свих нијанси језичке употребе изворног израза.

\section{3. Закључне напомене}

У закључку, можемо приметити да се преводилац одлучио за честе личне интервенције у тексту, пре свега ради боље читљивости текста, већег степена разумљивости и лакшег поимања света романа. Иако нема превише примера реченичне реорганизације у процесу превођења (осим када је то условљено правилима језичке употребе циљног језика), примењена дирекционална еквиваленција довела би до тога да повратни превод не би био подударан са изворним текстом. Имајући у виду да је техника додавања често примењивана, закључујемо да би нови текст који би се добио на српском био нешто дужи од текста са ког се преводило.

У чему лежи оправданост овог поступка? Додавање преводиоцу служи да би се разјаснио смисао и лакше перципирао одређени појам. Тако преводилац постаје саучесник у стварању дела на другом језику, односно могло би се говорити о дијалошком односу писца и преводиоца, тј. дела и превода. Суштинска разлика састојала би се у томе што писац ствара спонтаније, док стваралаштво преводиоца мора бити резултат свестране анализе структуре дела (Стојнић 1989: 41).

Иако подржавамо одлуку преводиоца да не пружа додатна објашњења речи и израза у напоменама на 
крају стране, јер би на тај начин фуснотама оптеретио текст, сматрамо да би превод глосара, који је писац додао на крају романа, у великој мери олакшао разумевање турцизама и осталих страних појмова и смањио преводилачку стратегију доместикације на прихватљиву меру. Тим пре што сам Иво Андрић преводну књижевност види као спону која повезује људе који припадају различитим културама и говоре различитим језицима:

Преводиоци су најбољи тумачи и посредници у овом одувек подељеном свету. Ако су данас народи и људи блиски једни другима, и оволико колико јесу, за то треба захвалити, између осталог, и преводиоцима. Ко се од нас није њиховим радом и напором користио? Шта би милиони људи знали о Хомеру, Дантеу или Гетеу да их не читају у преводима, а шта о Еурипиду, Шекспиру, Расину или Гогољу да их не слушају у позориштима на свом језику? Ништа. А ако ипак нешто знамо или бар наслућујемо, то је заслуга преводилаца. И сви ми, колико нас има, њихови смо дужници. (Андрић 1976)

Постоје одређени теоретичари који сматрају да је доместикација у процесу превођења цена коју вреди платити како би одређено књижевно дело било универзално препознато (Hatim \& Munday 2006: 100), односно да не би било занемарено на светској књижевној сцени као дело мањинске културе. Насупрот њима, поменули смо Венутијеву школу мишљења која оштро критикује англоамеричку праксу у којој је присутна доместикација преводне књижевности. Анализа превода романа Омер-паша Латас на енглески језик показала је да је преводилац користио стратегију која повремено одступа од Венутијевих захтева, али повремено их поштује примењујући дирекционалну еквиваленцију, односно 
тако што задржава Андрићеве лексичке особености уз краћу интратекстуалну глосу. Такође, приметан је труд да се задржи лепота стилског израза, као и да се пренесе изворно значење уз што мања одступања. Примери које смо навели у раду показују да су највеће „жртве” пале приликом превођења културолошких елемената изражених позајмљеницама из турског језика, јер је управо на овим местима примењена доместикација. Разлоге за такав приступ можемо наћи у жељи издавача и преводиоца да превод не оптерете одликама страног језика и културе како би био разумљив и питак савременом читаоцу.

\section{Извори и литература}

Андрић, И. „Са магијом понекад граничи и на праве подвиге личи рад доброг преводиоца”. Иво Андрић о превођену (1976). Kiveli Translations - grčki i srpski prevodi. Веб. 29.5.2019.

Андрић, И. Омер-паша Латас. Београд: Просвета, 1976. Штампано.

Андрић, И. Омер-паша Латас. Београд: Просвета, 1981. Штампано.

Andrić, I. Omer Pasha Latas: Marshal to the Sultan. Celia Hawkesworth (prev.). London: Penguin Random House, 2018. Електронско издање Амазона (киндл).

Бујас, Ж. Велики хрватско-енглески рјечник. Загреб: Накладни завод Глобус, 2005. Штампано.

Дрводелић, М. Енглеско-хрватски или српски рјечник. Загреб: Школска књига, 1973. Штампано.

Игњачевић, С. „Место књижевног превода у транслатологији". Мостови. Београд: Удружење књижевних преводилаца Србије, 1988, 113-122. Штампано.

Јовановић, М. О превођену - техника превођень са примерима српско-енглеског и енглеско-српског превода. Београд: Удружење научних и стручних преводилаца Србије, 2001. Штампано. 
Munday, J. Evaluation in Translation - critical points of translator decision-making. London \& New York: Routledge, 2012. Штампано.

Pym, A. Exploring Translation Theories. London \& New York: Routledge, 2010. Штампано.

Сибиновић, М. Књижевни превод као књижевно дело. Кюижевно превођене: теорија и историја. Пожаревац: Институт за књижевност и уметност, Књижевна заједница Новог Сада, 1989, 25-30. Штампано.

Стевановић, М. и др. Речник српскохрватскога кюижевног језика књига прва. Нови Сад, Загреб: Матица српска, 1967. Штампано.

Стевановић, М. и др. Речник српскохрватскога кюижевног језика книга друга. Нови Сад, Загреб: Матица српска, 1967. Штампано.

Стевановић, М. и др. Речник српскохрватскога книжевног језика књга четврта. Нови Сад: Матица српска, 1971. Штампано.

Стевановић, М. и др. Речник српскохрватскога књижевног језика книга шеста. Нови Сад: Матица српска, 1976. Штампано.

Стојнић, М. Превод као тумачење књижевног дела. Кюижевно превођене: теорија и историја. Пожаревац: Институт за књижевност и уметност, Књижевна заједница Новог Сада, 1989, 31-42. Штампано.

Hatim, B. \& J. Munday. Translation - an advanced resource book. Oxon: Routledge, 2006. Штампано.

Venuti, L. The Translator's Invisibility: A History of Translation. London \& New York: Routledge, 1995. Штампано.

Вујаклија, М. Лексикон страних речи и израза. Београд: Просвета, 1980. Штампано.

Wehmeier, S. Oxford Advanced Learner's Dictionary. Oxford: Oxford University Press, 2003. Штампано. 
Mirjana Daničić

Sandra Josipović

\author{
EVALUATING LITERATURE \\ IN TRANSLATION - A CASE STUDY: \\ OMER PASHA LATAS: MARSHAL TO THE SULTAN
}

The English translation of the novel Omer Pasha Latas: Marshal to the Sultan (1977) written by Ivo Andrić, a Nobel Prize winner, was published only on 30 October 2018. As the novel is characterized by complex structure, elegant language and stylistic excellence, the authors of the paper find this translation task a true feat. The authors have analyzed the translation strategies and solutions, taking into account the theory of directional equivalence (Pym 2010). The paper also assesses the intertextuality of the original novel and its translation in order to evaluate the equivalence of conveying an image of the world from one language to another.

Key words: Ivo Andrić, translatology, literary translation, equivalence, cultural domestication, linguistic domestication, intertextuality. 